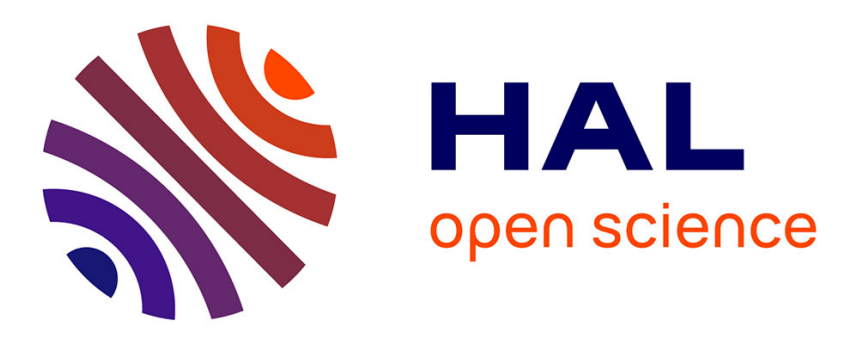

\title{
CD21 deficiency in two siblings with recurrent respiratory infections and hypogammaglobulinemia
}

Jeremie Rosain, Charline Miot, Nathalie Lambert, Marie-Christine Rousselet, Isabelle Pellier, Capucine Picard

\section{- To cite this version:}

Jeremie Rosain, Charline Miot, Nathalie Lambert, Marie-Christine Rousselet, Isabelle Pellier, et al.. CD21 deficiency in two siblings with recurrent respiratory infections and hypogammaglobulinemia . Journal of Allergy and Clinical Immunology, 2017, Epub ahead of print. 10.1016/j.jaip.2017.04.011 . inserm-01525046

\section{HAL Id: inserm-01525046 https://www.hal.inserm.fr/inserm-01525046}

Submitted on 19 May 2017

HAL is a multi-disciplinary open access archive for the deposit and dissemination of scientific research documents, whether they are published or not. The documents may come from teaching and research institutions in France or abroad, or from public or private research centers.
L'archive ouverte pluridisciplinaire HAL, est destinée au dépôt et à la diffusion de documents scientifiques de niveau recherche, publiés ou non, émanant des établissements d'enseignement et de recherche français ou étrangers, des laboratoires publics ou privés. 
3

\section{hypogammaglobulinemia}

Jeremie Rosain ${ }^{1,2}$ PharmD,MSci, Charline Miot $^{3,4,5}$ MD,PhD, Nathalie Lambert ${ }^{1}$, MSci, Marie-Christine Rousselet ${ }^{5,6} \mathrm{MD}, \mathrm{PhD}$, Isabelle Pellier ${ }^{3,4,5} \mathrm{MD}, \mathrm{PhD}$, Capucine Picard ${ }^{1,7}$

$$
\mathrm{MD}, \mathrm{PhD}
$$

1. Study Center for Primary Immunodeficiencies, Necker-Enfants Malades Hospital, Assistance Publique Hôpitaux de Paris (APHP), Necker Medical School, Paris, France, EU.

2. Paris Descartes University, Paris, France, EU.

3. Pediatric Immuno-Hemato-Oncology Unit, Angers University Hospital, France, EU.

4. Inserm UMR 892, Angers, France, CNRS UMR 6299, Angers, France, EU.

5. Angers University, Angers, France, EU.

6. Department of Cellular and Tissue Pathology, Angers University Hospital, France, EU.

7. INSERM UMR1163, Imagine Institute, Paris Descartes University, Paris, France, EU.

\section{Corresponding author:}

Capucine Picard, Study Center for Primary Immunodeficiencies, Necker - Enfants Malades Hospital, 149 rue de Sèvres, 75015 Paris, France, EU. Phone number +33 (1) 444950 88; fax number +33 (1) 427306 40; capucine.picard@inserm.fr

\section{Short summary}

We report the clinical history, immunological phenotype and causal mutation for two patients with CD21 deficiency.

\section{Keywords}

Primary antibody deficiency, CD21, respiratory infections

\section{Abbreviations}

CVID: common variable immunodeficiency 


\section{To the Editor,}

(1)

The complement system plays a major role in humoral immunity via activation of the classical pathway and the development of adaptive responses. This function is ensured principally by $\mathrm{CD} 21$ (or $\mathrm{CR} 2$ ), a receptor that recognizes $\mathrm{C} 3$ cleavage fractions containing a C3d moiety bound to an antigen ${ }^{1}$. CD21 is primarily expressed by follicular dendritic cells (FDC) and B cells. The CD21 on FDCs traps soluble C3d-bound antigens for their presentation to B cells in the lymphoid tissues. The CD21 on B cells forms part of the CD19 complex, along with CD81, CD225 and CD19, and acts as a coreceptor for the B-cell receptor (BCR)-Ig $\alpha \beta$. The coligation of a C3d-bound antigen to the BCR and CD21 increases the strength of the activating signal delivered to $\mathrm{B}$ cells ${ }^{1}$. Only two patients with a common variable immunodeficiency syndrome (CVID) phenotype caused by autosomal recessive CD21 deficiency have been reported to date ${ }^{2,3}$. We report here the first multiplex kindred with CD21 deficiency.

The two siblings were born to consanguineous French parents (Figure E1). The proband (P1), a 14-year-old girl, was first referred at the age of seven years, for recurrent otitis media and bronchitis, which persisted despite three adenoidectomies and multiple grommet insertions. She also had undocumented lobar pneumonia at the age of 12 years. Immunological tests performed at the age of seven years revealed low levels of immunoglobulin (Ig) G1, resulting in low levels of IgG. IgG and IgG1 levels were normal at the age of 10 years. IgG to tetanus and diphtheria were reduced despite routine immunization (Table E1). This patient developed partial conductive deafness, despite the systematic treatment of otitis media with antibiotics. Histological analysis of an adenoid sample showed a hypertrophic mucosa with florid hyperplasia of the secondary lymphoid follicles. Germinal centers contained large numbers of macrophages, the cell bodies of which were readily stained. Interfollicular areas contained 
lymphocytes, marginal cells, immunoblasts and plasmocytes, with no cellular atypia (Figure E2). P1's 11-year-old brother (P2) was first referred at the age of five years, for recurrent otitis media, rhinopharyngitis and bronchitis, which have begun at the age of four months. He underwent one adenoidectomy and two grommet insertions. Initial immunological explorations showed normal levels of IgG but slightly low levels of IgG1. P2 then developed mild hypogammaglobulinemia between the ages of 7 and 11 years. IgG to tetanus and diphtheria were reduced despite routine immunization. After booster injections, the titers of antibodies specific for tetanus toxoid reached protective levels in the two patients, whereas those for anti-diphtheria toxoid antibodies remained low (Table E1 and Figure E2). None of the two patients received immunoglobulin substitution. P1 received prophylaxis by cotrimoxazole during one winter season at the age of 7 which reduced the frequency of infections. A flow-cytometry study of B cells from the two patients showed a decrease in class-switched memory B cells and a complete loss of CD21 cell surface expression (Figure E1). CD21 immunohistochemistry of the adenoid tissue of P1 revealed a complete absence of staining (Figure E2). Genomic sequencing of $C R 2$, the gene encoding CD21, revealed a homozygous one-base pair deletion (c.234delC) predicted to lead to a frameshift and the insertion of a premature stop codon (p.T209HfsX10) (Figure E1). Both parents were heterozygous for this mutation. The father was asymptomatic and had a normal immunophenotype, with slightly lower levels of CD21 expression on B cells than observed in the healthy control (Figure E1). The mother was asymptomatic but had had recurrent otitis media during childhood. Laboratory assessments revealed profound B lymphopenia (0.9\%; $3 / \mathrm{mm}^{3}$ ), but normal levels of immunoglobulins and a protective titer of antibodies against toxoid tetanus in the mother at the age of 35 years.

We report here complete CD21 deficiency due to a new homozygous $C R 2$ mutation in two siblings. Both patients were referred for recurrent upper respiratory tract infections beginning 
in early childhood. Both have mild hypogammaglobulinemia and low levels of memory classswitched B cells, with impaired production of antibodies specific for certain protein antigens. The adenoid tissue of P1 had hyperplastic germinal centers with a normal architecture but no CD21-positive FDCs. The number and size of germinal centers within splenic follicles are smaller after immunization in $\mathrm{cr} 2^{-/-}$mice than in wild-type mice ${ }^{4}$, probably because $\mathrm{cr} 2^{-/}$mice are also CD35-deficient ${ }^{1}$. CD35 is another receptor of cleaved complement fractions ${ }^{4}$. Only two other CD21-deficient patients have been described to date $e^{2,3}$. Both have mild hypogammaglobulinemia associated with low levels of memory B cells, but they have a normal antibody response to protein antigens ${ }^{2,3}$ (Table 1). The first patient reported was diagnosed at the age of 26 years. He had recurrent upper respiratory tract infections before the age of six years and remained asymptomatic for 20 years following adenoidectomy ${ }^{2}$. At the age of 26 years, he developed symptoms suggestive of CVID. The second reported case was a 16 year old boy with a history of autoimmune disease with no history of recurrent infection ${ }^{3}$. The two patients reported here had more severe clinical and immunological phenotypes than the first two patients to be described ${ }^{2,3}$ (Table 1). As our patients were born to consanguineous parents, we cannot rule out the existence of other pathogenic variants in their genomes, although laboratory investigations detected no other immunological abnormality.

Low levels of calcium flux have been reported in CD21-deficient B cells exposed to a suboptimal quantity of C3d-bound antigen ${ }^{2}$. This finding suggests that the impaired B-cell response in $\mathrm{CD} 21$-deficient patients is due to decreased stimulation of $\mathrm{B}$ cells from the germinal center in the absence of positive signals mediated via the CD21 coreceptor ${ }^{1}$. The absence of CD21 expression on FDCs may also be responsible for impaired antigen retention in lymphoid follicles. Taken together, these data suggest that the absence of CD21 expression on B cells and FDCs could lead to an inability to sustain specific humoral responses after antigen challenge. This finding highlights the importance of CD21 for the development of 
108 humoral adaptive immunity and the induction of memory B cells in humans. CD21 deficiency

109 may however be surmountable in case of high concentration or repeated antigen exposure ${ }^{2}$.

110 Other deficiencies in components of the CD19 complex (CD19 and CD81 deficiencies) are

111 also associated with an impaired response to protein antigens, albeit with a more severe

112 clinical and immunological phenotype than in CD21 deficiency ${ }^{3,5-9}$. This underlie that CD21

113 may be more redundant than CD19 and CD81. Additional clinical reports for CD21-deficient

114 patients and their long term follow-up are now required to improve our understanding of the

115 natural course of this deficiency. The defect observed in these patients could easily be

116 screened by flow cytometry panel for CVID, which should be offered to patients with an

117 impairment of humoral immunity.

120 Acknowledgment: We would like to thank Mirjam van der Burg, Jacinta Bustamante,

121 Véronique Frémeaux-Bacchi and Ludovic Lhermitte for helpful discussions. We also thank

122 Aminata Diabate, Barik Konte, Stéphanie Ndaga and Corinne Jacques for excellent technical

123 assistance. 


\section{References}

125 1. Carroll MC, Isenman DE. Regulation of humoral immunity by complement. Immunity 126 2012; 37:199-207.

127 2. Thiel J, Kimmig L, Salzer U, Grudzien M, Lebrecht D, Hagena T, et al. Genetic CD21

128 deficiency is associated with hypogammaglobulinemia. J Allergy Clin Immunol 2012;

129 129:801-10 e6.

130 3. Wentink MW, Lambeck AJ, van Zelm MC, Simons E, van Dongen JJ, H IJ, et al.

131 CD21 and CD19 deficiency: Two defects in the same complex leading to different disease

132 modalities. Clin Immunol 2015; 161:120-7.

133 4. Ahearn JM, Fischer MB, Croix D, Goerg S, Ma M, Xia J, et al. Disruption of the Cr2

134 locus results in a reduction in B-1a cells and in an impaired B cell response to T-dependent

135 antigen. Immunity 1996; 4:251-62.

136 5. van Zelm MC, Reisli I, van der Burg M, Castano D, van Noesel CJ, van Tol MJ, et al.

137 An antibody-deficiency syndrome due to mutations in the CD19 gene. N Engl J Med 2006;

138 354:1901-12.

139 6. Kanegane H, Agematsu K, Futatani T, Sira MM, Suga K, Sekiguchi T, et al. Novel

140 mutations in a Japanese patient with CD19 deficiency. Genes Immun 2007; 8:663-70.

141 7. van Zelm MC, Smet J, Adams B, Mascart F, Schandene L, Janssen F, et al. CD81

142 gene defect in humans disrupts CD19 complex formation and leads to antibody deficiency. J

143 Clin Invest 2010; 120:1265-74.

1448 8. Vince N, Boutboul D, Mouillot G, Just N, Peralta M, Casanova JL, et al. Defects in

145 the CD19 complex predispose to glomerulonephritis, as well as IgG1 subclass deficiency. J

146 Allergy Clin Immunol 2011; 127:538-41 e1-5.

147 9. van Zelm MC, Smet J, van der Burg M, Ferster A, Le PQ, Schandene L, et al.

148 Antibody deficiency due to a missense mutation in CD19 demonstrates the importance of the

149 conserved tryptophan 41 in immunoglobulin superfamily domain formation. Hum Mol Genet

150 2011; 20:1854-63. 
Table 1 - Clinical, immunological and genetic characteristics of CD21-deficients patients

\begin{tabular}{|c|c|c|c|c|}
\hline & Thiel et al., $2012^{2}$ & Wentink et al., $2015^{3}$ & P1 & $\mathbf{P 2}$ \\
\hline Age at diagnosis & $26 \mathrm{y}$ & $13 y$ & $14 \mathrm{y}$ & $11 \mathrm{y}$ \\
\hline Sex & $\mathrm{M}$ & $\mathrm{M}$ & $\mathrm{F}$ & $\bar{M}$ \\
\hline Country of residence & Germany & The Netherlands & France & France \\
\hline Consanguinity & No & No & Yes & Yes \\
\hline Clinical history & $\begin{array}{c}<6 \text { y: URT infections } \\
6-26 \text { y: asymptomatic } \\
26 \text { y: URT and LRT infections, } \\
\text { SMG, diarrhea, fever }\end{array}$ & $\begin{array}{l}\text { No recurrent infection } \\
\text { Possible autoimmune } \\
\text { disease }\end{array}$ & $\begin{array}{l}\text { Recurrent URT } \\
\text { and LRT } \\
\text { infections since } \\
\text { early childhood }\end{array}$ & $\begin{array}{c}\text { Recurrent URT } \\
\text { infections since early } \\
\text { childhood }\end{array}$ \\
\hline CR2 mutations & $\begin{array}{c}\text { c. } 1225+1 \mathrm{G}>\mathrm{C} / \\
\text { p.W766X }\end{array}$ & $\begin{array}{c}\text { p.R142X/ } \\
\text { p.I926SfsX14 }\end{array}$ & $\begin{array}{l}\text { p.T209HfsX10/ } \\
\text { p.T209HfsX10 }\end{array}$ & $\begin{array}{l}\text { p.T209HfsX10/ } \\
\text { p.T209HfsX10 }\end{array}$ \\
\hline $\begin{array}{l}\text { Immunophenotyping } \\
\text { CD21 expression } \\
\text { Class-switched memory B } \\
\text { cells } \\
\end{array}$ & $\begin{array}{c}\text { Absent } \\
\text { Decreased }\end{array}$ & $\begin{array}{c}\text { Absent } \\
\text { Decreased }\end{array}$ & $\begin{array}{c}\text { Absent } \\
\text { Decreased }\end{array}$ & $\begin{array}{c}\text { Absent } \\
\text { Decreased }\end{array}$ \\
\hline $\begin{array}{c}\text { Immunoglobulin } \\
\text { IgG } \\
\operatorname{IgA} \\
\operatorname{IgM} \\
\end{array}$ & $\begin{array}{l}\text { Low } \\
\text { Low } \\
\text { Normal } \\
\end{array}$ & $\begin{array}{l}\text { Low } \\
\text { Low } \\
\text { Low } \\
\end{array}$ & $\begin{array}{c}\text { Low to normal } \\
\text { Normal } \\
\text { Normal } \\
\end{array}$ & $\begin{array}{c}\text { Low to normal } \\
\text { Normal } \\
\text { Subnormal } \\
\end{array}$ \\
\hline $\begin{array}{c}\text { Serology } \\
\text { Protein antigens } \\
\text { Polysaccharide antigen }\end{array}$ & $\begin{array}{l}\text { Normal } \\
\text { Low }\end{array}$ & $\begin{array}{l}\text { Normal } \\
\text { Normal }\end{array}$ & $\begin{array}{c}\text { Low } \\
\text { Normal* }\end{array}$ & $\begin{array}{l}\text { Low } \\
\text { Low* }\end{array}$ \\
\hline
\end{tabular}

*assessed by blood group isohemagglutin production; URT: upper respiratory tract; LRT: lower respiratory tract; SMG: splenomegaly 